\title{
The Investigation of a Novel Indicator System for Trace Determination and Speciation of Selenium in Natural Water Samples by Kinetic Spectrophotometric Detection
}

\author{
Ramazan GÜRKAN* and Halil İbrahim ULUSOY \\ University of Cumhuriyet, Faculty of Science \& Arts, Department of Chemistry, TR-58140, Sivas, Turkey \\ *E-mail:rgurkan@cumburiyet.edu.tr \\ Received February 11, 2010, Accepted May 6, 2010
}

\begin{abstract}
A novel catalytic kinetic method is proposed for the determination of $\mathrm{Se}(\mathrm{IV}), \mathrm{Se}(\mathrm{VI})$ and total inorganic selenium in water based on the catalytic effect of Se(IV) on the reduction of bromate by $p$-nitrophenylhydrazine at $\mathrm{pH} 3.0$. The generated bromine, $\mathrm{Br}_{2}$ or $\mathrm{Cl}_{2}$ plus $\mathrm{Br}_{2}$ in $0.1 \mathrm{M} \mathrm{NaCl}$ (or $\mathrm{NaBr}$ ) environment efficiently decolorized Calmagite and the reaction was monitored spectrophotometrically at $523 \mathrm{~nm}$ as a function of time. In this indicator reaction, bromide acted as an activator for the catalysis of selenium (IV) and a reducing agent for selenium (VI) at pH 3.0, which allowed the determination of total selenium. The fixed time method was adopted for the determination and speciation of inorganic selenium. Under the optimum conditions, the calibration graph are linear in the range $1-35 \mu \mathrm{g} \mathrm{L}^{-1}$ of $\mathrm{Se}(\mathrm{IV})$ for the fixed time method at $25^{\circ} \mathrm{C}$. The detection limit based on statistical $3 \mathrm{~S}_{\text {blank }} / \mathrm{m}$-criterion was $0.215 \mu \mathrm{g} \mathrm{L}^{-1}$ for the fixed time method $(7 \mathrm{~min})$. All of the variables that affect the sensitivity at $523 \mathrm{~nm}$ were investigated, and the optimum conditions were established. The interference effect of various cations and anions on the Se (IV) determination was also studied. The selectivity of the selenium determination was greatly improved with the use of the strongly cation exchange resin such as Amberlite IR120 plus. The proposed kinetic method was validated statistically and through recovery studies in natural water samples. The RSDs for ten replicate measurements of 5,15 and $25 \mu \mathrm{g} \mathrm{L}^{-1}$ of $\mathrm{Se}(\mathrm{IV})$ and $\mathrm{Se}(\mathrm{VI})$ was changed between 2.1 - 4.85\%. Analyses of a certified standard reference material (NIST SRM 1643e) for selenium using the fixed-time method showed that the proposed kinetic method has good accuracy. $\mathrm{Se}(\mathrm{IV}), \mathrm{Se}(\mathrm{VI})$ and total inorganic selenium in environmental water samples have been successfully determined by this method after selective reduction of $\mathrm{Se}(\mathrm{VI})$ to $\mathrm{Se}(\mathrm{IV})$.
\end{abstract}

Key Words: Selenium speciation and determination, Calmagite, Catalytic effect, Kinetic spectrophotometry, Natural waters

\section{Introduction}

The determination of selenium in natural waters has received great attention during the past years owing to the biological importance of this element. Selenium is an essential trace element but at elevated levels it is toxic to biological systems. ${ }^{1-2}$ It is generally recognized that the toxicity and the bioavailability are controlled not only by the total concentration but also by the chemical forms. The physiological behavior of selenium is dependent upon its oxidation state $\mathrm{Se}(\mathrm{IV}), \mathrm{Se}(\mathrm{VI})$ and $\mathrm{Se}(-\mathrm{II})$, selenide being generally present in organic forms (selenocysteine, selenomethionine, methylated compounds). The concentration of selenium generally encountered in natural waters is in the $n g \mathrm{~L}^{-1}$ or sub-mg L ${ }^{-1}$ range. So it is important to have selective and sensitive methods to identify each species and determine their levels.

Over the past two decades various instrumental techniques including UV-visible spectrophotometry, ${ }^{3}$ atomic/molecular fluorescence spectrometry, ${ }^{4-7}$ high performance liquid chromatography, ${ }^{5}$ hydride generation atomic absorption spectrometry, ${ }^{8-12}$ differential pulse cathodic stripping voltammetry, ${ }^{13}$ inductively coupled plasma mass spectrometry, ${ }^{14}$ ion chromatography ${ }^{15-16}$ and flow injection analysis coupled with hydride generation atomic fluorescence spectrometry ${ }^{17}$ have been developed and used for Se speciation.

However, the catalytic kinetic spectrophotometric methods offer distinct advantages for being of high sensitivity, low cost and simplicity for a large majority of analytes in water samples. ${ }^{18-22}$ A significant number of methods for selenium determination in real samples are based on catalytic effect of Se(IV) on the reduction of dyes such as Toluidine blue, ${ }^{23}$ Methylene blue, ${ }^{24}$ Gallocyanin, ${ }^{25}$ Semicarbazide ${ }^{26}$ and Ponceau S. ${ }^{27}$ Some of these methods have high limit of detection, or suffer from many interfering ions such as Te(IV) and As(III), or have time consuming procedures, or these reagents used are unstable. Additionally, few catalytic kinetic methods for the determination of $\mathrm{Se}(\mathrm{IV})$ in water systems have been reported in the literature as presented in Table $1^{28-35}$ but only one catalytic kinetic method ${ }^{36}$ exists which allows the determination of $\mathrm{Se}(\mathrm{IV}), \mathrm{Se}(\mathrm{VI})$ and total inorganic Se in water samples. Therefore, there is still need to develop the more sensitive and selective catalytic kinetic spectrophotometric method for the determination and speciation of selenium in real samples.

We found that bromate slowly reacts with $p$-nitrophenylhydrazine using Calmagite as chromogenic reagent in weak acidic media and $\mathrm{Se}(\mathrm{IV})$ catalytically accelerates this reduction reaction at $523 \mathrm{~nm}$. In the present study, a sensitive and selective catalytic spectrophotometric method is described for the determination of $\mathrm{Se}(\mathrm{IV})$ and $\mathrm{Se}(\mathrm{VI})$ by using reduction of $\mathrm{Se}(\mathrm{VI})$ to $\mathrm{Se}(\mathrm{IV})$ and the $\mathrm{Se}(\mathrm{IV})$-catalyzed reaction of bromate with $p$ nitrophenylhydrazine in the presence of Calmagite. The proposed method could simultaneously determine Se(IV) and (IV + VI) in the concentration range of 1 - $35 \mu \mathrm{g} \mathrm{L}^{-1}$ without serious interferences, which allows to monitor easily the selenium species. 
Table 1. Comparison of some catalytic kinetic spectrophotometric methods for determination of selenium in natural waters and real samples

\begin{tabular}{|c|c|c|c|c|}
\hline Reagents & $\begin{array}{l}\text { Detection limit, } \\
\text { detection range, } \\
\mu \mathrm{g} \mathrm{L}^{-1} \text { or } \mu \mathrm{gL}^{-1}\end{array}$ & Remarks & Sample(s) & Ref. \\
\hline Toluidine blue, Sulfide & $0.08,0.2-2$ & $\begin{array}{l}\text { Flow injection spectrophotometry, The method is suit- } \\
\text { able for routine analysis; about } 35 \text { samples can be } \\
\text { injected per hour. }\end{array}$ & $\begin{array}{l}\text { Ores and pharma- } \\
\text { ceutical preparations }\end{array}$ & [23] \\
\hline Methylene blue, Sulfide & $2.5-30$ & $\begin{array}{l}\text { Induction period method, the catalytic method was } \\
\text { applied to urine samples with } 84.9 \% \text { recovery }\end{array}$ & $\begin{array}{l}\text { Blood, hair and urine } \\
\text { samples }\end{array}$ & {$[24]$} \\
\hline Gallocyanin, Sulfide & $0.002,0.010-0.500$ & $620 \mathrm{~nm}, 30{ }^{\circ} \mathrm{C}$ & Real samples & {$[25]$} \\
\hline $\begin{array}{l}\text { Semicarbazide, Hydrazine, } \\
\text { Bromate }\end{array}$ & $43,50-4000$ & $\begin{array}{l}\text { The method is based on the catalytic effect of } \mathrm{Se}(\mathrm{IV}) \\
\text { in redox reaction of bromate with semicarbazide in } \\
\text { hydrochloric acid media. }\end{array}$ & $\begin{array}{l}\text { Kjeldahl tablets and a } \\
\text { health-care product }\end{array}$ & [26] \\
\hline $\begin{array}{l}\text { Ponceau S, Bromate, } \\
\text { Hydrazine }\end{array}$ & $3.3,4.5-400$ & $\begin{array}{c}525 \mathrm{~nm} \text {, initial rate(or slope) method, } \mathrm{pH} 1.4,40^{\circ} \mathrm{C} \text {, } \\
\text { There is a serious interfering arising from } \mathrm{As}(\mathrm{III}) \text { and } \\
\text { Te(IV) ions }\end{array}$ & $\begin{array}{l}\text { Spiked water, kjeldahl } \\
\text { tablet, Selenium tablet, } \\
\text { Shampoo }\end{array}$ & {$[27]$} \\
\hline $\begin{array}{l}\text { Bromate, Hydrazine sulfate, } \\
\text { Ascorbic acid, Activated } \\
\text { carbon, Methyl orange }\end{array}$ & $0.012,0.02-20.0$ & $\begin{array}{c}525 \mathrm{~nm} \text {, preconcentration of Se, fixed time method } \\
(30 \mathrm{~s}) \text {, recovery } 89-105 \% \text {, RSD } 1.0-7.1 \% \text { for Se(IV) } \\
\text { and } \mathrm{Se}(\mathrm{VI})\end{array}$ & Environmental water & [28] \\
\hline Methylene blue, Sulfide & $2.5-30$ & $\begin{array}{l}668 \mathrm{~nm} \text {, interference removed with organic solvents, } \\
\text { room temperature; recovery } 91.8 \% \text { and RSD } 2.3 \% \\
\text { for } 15 \mathrm{ppb}\end{array}$ & Natural water & [29] \\
\hline Maxilon blue-SG, Sulfide & $0.205,0.004-0.200$ & $\begin{array}{l}654 \mathrm{~nm} \text {, fixed time method }(4.0 \mathrm{~min}), 30.0{ }^{\circ} \mathrm{C}, \mathrm{pH} 6.5 \\
\text { interference removed by cation-exchange resin, } \\
\text { recovery }>91 \%, \mathrm{RSD}<2.27 \% \text { for } 0.004-0.16 \mu \mathrm{gL} \mathrm{m}^{-1}\end{array}$ & Spring water & {$[30]$} \\
\hline Sulfonazo, Sulfide & $\begin{array}{l}0.3,0.5-180 \text { and } \\
50-2300\end{array}$ & $\begin{array}{l}680 \mathrm{~nm} \text {, by fixed time method; interference removal } \\
\text { with cation exchange resin }\end{array}$ & $\begin{array}{l}\text { Natural and synthetic } \\
\text { water }\end{array}$ & [31] \\
\hline $\begin{array}{l}p \text {-Hydrazinobenzene-sul- } \\
\text { fonic acid (HBS), } N \text {-(1- } \\
\text { Naphthyl) ethylene-diamine } \\
\text { (NED), Bromide }\end{array}$ & $0.2-6$ & $\begin{array}{l}538 \mathrm{~nm} \text {, flow injection with two schemes, } 25^{\circ} \mathrm{C} \text { and } \\
100{ }^{\circ} \mathrm{C}, \mathrm{RSD} 1.2 \text { and } 1.3 \% \text { for } 3 \mathrm{ng} \mathrm{m}^{-1} \mathrm{Se}(\mathrm{IV}) \text { and } \\
\operatorname{Se}(\mathrm{VI})(n=10)\end{array}$ & Natural water & [32] \\
\hline $\begin{array}{l}\text { Iron(II) ethylenediamine- } \\
\text { tetraacetate, } 4 \text {-Nitroaniline, } \\
\text { Nitrate, } N \text {-Diethyl- } N \text {-(1- } \\
\text { naphthyl)-ethylenediamine }\end{array}$ & 0.1 & $\begin{array}{l}540 \mathrm{~nm} \text {, interference removal by ultrasonic } \\
\text { treatment, RSD } 6 \% \text { and } 2 \% \text { for } 0.2 \text { and } 2 \mathrm{ng} \mathrm{mL}^{-1} \mathrm{Se}\end{array}$ & $\begin{array}{l}\text { Potable and natural } \\
\text { water }\end{array}$ & [33] \\
\hline $\begin{array}{l}\text { Etheylenediamine tetrecetic } \\
\text { acid disodium salt (EDTA), } \\
\text { Nitrate, Ammonium } \\
\text { iron(II) sulfate hexahydrate }\end{array}$ & $\begin{array}{l}2.5-200 \text { and } \\
200-2000\end{array}$ & $\begin{array}{l}\text { Flow injection with } 7 \mathrm{samples}^{-1} \text {, recovery } 95-104 \% \\
\text { RSD } 3.4 \% \text { for } 5 \times 10^{-8} \mathrm{~g} \mathrm{~mL}^{-1} \mathrm{Se}(\mathrm{IV})(n=11), 2.7 \% \\
\text { for } 5 \times 10^{-7} \mathrm{~g} \mathrm{~mL}^{-1} \mathrm{Se}(\mathrm{IV})(n=11)\end{array}$ & Seawater & {$[34]$} \\
\hline $\begin{array}{l}\text { 4,5-Dihydroxy-3-( } p \text {-sulfo- } \\
\text { phenylazo)-2,7-naphthalene } \\
\text { disulfonic acid, Sulfide }\end{array}$ & $0.3,0.5-100$ & $\begin{array}{l}515 \mathrm{~nm} \text {, RSD } 2.10 \text { and } 1.95 \% \text { for } 0.02 \text { and } 0.10 \mu \mathrm{gL}^{-1} \\
\text { Se(IV), fixed time method }(2.5-7.0 \mathrm{~min})\end{array}$ & Natural water & {$[35]$} \\
\hline $\begin{array}{l}\text { Bromate, Hydrazine dihy- } \\
\text { drochloride, Methyl orange }\end{array}$ & $1.3,0-789.6$ & $\begin{array}{l}507 \mathrm{~nm} \text {, recovery } 97-102 \%, \mathrm{RSD}<6 \% \text { for } 31.6 \text { - } \\
126.3 \mu \mathrm{g} \mathrm{L} \mathrm{L}^{-1} \mathrm{Se}(\mathrm{IV}) \text { and } \mathrm{Se}(\mathrm{VI})(n=5), 25^{\circ} \mathrm{C}, \mathrm{pH} 1.6 \\
\text { fixed time }(5 \mathrm{~min}) \text { and initial rate methods }\end{array}$ & $\begin{array}{l}\text { Drinking, natural and } \\
\text { synthetic water }\end{array}$ & [36] \\
\hline $\begin{array}{l}\text { Bromate, } p \text {-Nitrophenyl- } \\
\text { hydrazine, Calmagite }\end{array}$ & $0.215,1-35$ & $\begin{array}{l}523 \mathrm{~nm} \text {, recovery } 99.2-105 \% \text {, RSD } 2.1-4.85 \% \text { for } \\
2-20 \mu \mathrm{g} \mathrm{L}^{-1} \text { of } \mathrm{Se}(\mathrm{IV}) \text { and } \mathrm{Se}(\mathrm{VI})(n=5), 25^{\circ} \mathrm{C}, \mathrm{pH} \\
3.0 \text { acetate buffer, fixed time }(7 \mathrm{~min}) \text { method }\end{array}$ & $\begin{array}{l}\text { River water, lake water } \\
\text { and certified Standard } \\
\text { reference material }\end{array}$ & $\begin{array}{l}\text { The } \\
\text { present } \\
\text { study }\end{array}$ \\
\hline
\end{tabular}


The method has successfully been applied to the determination of Se(IV) and (VI) in spiked natural water samples such as lake water and river water.

\section{Experimental}

Apparatus. In the present study, a Shimadzu model UVvisible $1601 \mathrm{PC}$ spectrophotometer equipped with a $1 \mathrm{~cm}$ quartz cell and a temperature-controlled cell holder (TCC-140A) was used for absorbance measurements at a fixed wavelength of $523 \mathrm{~nm}$. A Grant LTG-6G model thermostatic water bath was used to control the temperature of reaction medium with an accuracy of $\pm 0.1^{\circ} \mathrm{C}$. A stopwatch was used for recording the reaction time. All solutions were preheated to a temperature of $25{ }^{\circ} \mathrm{C}$ shortly before the initiation of indicator reaction with and without catalyst. A Sartorious Docu-model pH meter supplied with a combined electrode $\mathrm{pH}$ meter was calibrated with standard buffers of $\mathrm{pH} 4.0 \pm 0.1$ and $7.0 \pm 0.1$ and used for measuring $\mathrm{pH}$ of solutions.

Reagents and solutions. All chemicals were of analytical reagent grade. All solutions were made up in Triply distilled, de-ionized water. A $0.01 \mathrm{M} \mathrm{Se}(\mathrm{IV})$ standard solution was prepared by dissolving $0.173 \mathrm{~g}$ of $\mathrm{Na}_{2} \mathrm{SeO}_{3}$ in $100 \mathrm{~mL}$ water. $\mathrm{A}$ $0.01 \mathrm{M} \mathrm{Se}(\mathrm{VI})$ standard solution was prepared by dissolving $0.1889 \mathrm{~g}$ of $\mathrm{Na}_{2} \mathrm{SeO}_{4}$ in $100 \mathrm{~mL}$ water. A $1000 \mathrm{mg} \mathrm{L}^{-1}$ stock calmagite solution was prepared by dissolving $0.10 \mathrm{~g}$ of calmagite in $100 \mathrm{~mL}$ water. A $0.05 \mathrm{M}$ bromate solution was prepared by dissolving $0.835 \mathrm{~g} \mathrm{KBrO}_{3}$ in $100 \mathrm{~mL}$ water. A $0.05 \mathrm{M}$ $p$-nitrophenylhydrazine solution was prepared by dissolving $0.5249 \mathrm{~g} p$-nitrophenylhydrazine in approximately $2 \mathrm{~mL} 2 \mathrm{M}$ $\mathrm{H}_{3} \mathrm{PO}_{4}$ and diluting with water up to $100 \mathrm{~mL}$ water. The HAc/ Ac buffer solution of $100 \mathrm{~mL}$ pH 3 was prepared from $0.1 \mathrm{M}$ HAc and 1.0 M NaAc solutions.

General procedure. All solutions were thermally equilibrated at $25{ }^{\circ} \mathrm{C}$ in a thermostatic water bath before addition of reagents. A suitable portion of $\mathrm{Se}(\mathrm{IV})$ solution in the range of $1-35 \mu \mathrm{g} \mathrm{L}^{-1}$ was added into a $10 \mathrm{~mL}$ calibrated flask, then $1.5 \mathrm{~mL}$ of $\mathrm{pH} 3.0$
HAc/Ac buffer solution, $0.5 \mathrm{~mL} 0.005 \mathrm{M} p$-nitrophenylhydra-

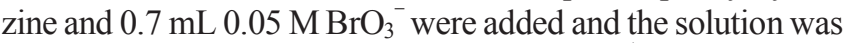
diluted to about $7 \mathrm{~mL}$. After $2.5 \mathrm{~mL} 50 \mathrm{mg} \cdot \mathrm{L}^{-1}$ calmagite was added, the mixture was diluted to $10 \mathrm{~mL}$. Time was measured just after the addition of the last drop of calmagite solution. The solution was mixed and a portion of that was transferred within $30 \mathrm{~s}$ into a $1 \mathrm{~cm}$ spectrophotometric cell to measure the absorbance change $\left(\Delta \mathrm{A}_{\mathrm{C}}\right)$ against water at $523 \mathrm{~nm}$ over the period $0.5-7.0 \mathrm{~min}$ after the initiation of the reaction by using fixed-time method. By the use of a serial of standard Se(IV) solution, a calibration graph of net change of absorbance, $\Delta(\Delta \mathrm{A})$ at a fixed time versus selenium (Se(IV)) concentration was constructed. The detailed calibration data are given in Table 2 as follows.

Recommended procedures for inorganic Se speciation in water samples. Selenium content in water samples was found below the detection limit of the method. Thus the environmental water samples were spiked simultaneously with Se(IV) and $\mathrm{Se}(\mathrm{VI})$ standards giving three different concentrations of 5, 10 and $20 \mu \mathrm{g} \mathrm{L}^{-1}$ and the recovery for Se(IV) was carried out using fixed time method of $7 \mathrm{~min}$. The content of $\mathrm{Se}(\mathrm{VI})$ in the spiked samples was determined after reducing procedures. ${ }^{37}$ For reduction $25 \mathrm{~mL}$ of the spiked solution was mixed with $25 \mathrm{~mL}$ of $12 \mathrm{M} \mathrm{HCl}$ in a $100 \mathrm{~mL}$ capped hard glass test-tube and heated in a water bath at $90{ }^{\circ} \mathrm{C}$ for $30 \mathrm{~min}$ where $\mathrm{Se}(\mathrm{VI})$ is quantitatively reduced to $\mathrm{Se}(\mathrm{IV})$. The resulting solution was diluted to $100 \mathrm{~mL}$ with $6 \mathrm{M} \mathrm{NaOH}$ solution to adjust the $\mathrm{pH} .^{37}$ The analysis for total Se(IV) was carried out using recommended fixed time method. The Se(VI) was determined as a difference between the recovered total inorganic $\mathrm{Se}(\mathrm{IV})$ found after reduction and $\mathrm{Se}(\mathrm{IV})$ found without reduction.

\section{Results and Discussion}

Preliminary studies. For the optimization of indicator reaction, the impact of reaction variables such as $\mathrm{KBrO}_{3}$, $p$-nitrophenylhydrazine, calmagite, ionic strength and temperature

Table 2. Analytical characteristics for the determination of [Se(IV)] using fixed time method in the range $1-35 \mu \mathrm{g} \mathrm{L}^{-1}$ under optimum conditions of $[$ Calmagite $]=12.5 \mathrm{mg} \mathrm{L}^{-1},\left[\mathrm{BrO}_{3}{ }^{-}\right]=3.5 \times 10^{-3} \mathrm{M},[p$-nitrophenylhydrazine $]=2.5 \times 10^{-3} \mathrm{M}, 1.5 \mathrm{~mL} \mathrm{pH} 3$ acetate buffer, temperature $=$ $25^{\circ} \mathrm{C}$ at $\lambda_{\max }: 523 \mathrm{~nm}$

\begin{tabular}{|c|c|c|c|c|c|c|}
\hline \multirow{2}{*}{ Parameters } & \multicolumn{6}{|c|}{ Fixed-time method } \\
\hline & $1 \mathrm{~min}$ & $3 \mathrm{~min}$ & $5 \mathrm{~min}$ & $7 \mathrm{~min}$ & $9 \min$ & $12 \mathrm{~min}$ \\
\hline $\begin{array}{l}\text { Linear dynamic } \\
\text { range, ng mL }\end{array}$ & $1-35$ & $1-35$ & $1-35$ & $1-35$ & $1-35$ & $1-35$ \\
\hline $\begin{array}{c}\text { Linear regression } \\
\text { equation }\end{array}$ & $\begin{array}{l}\Delta A_{1}=9.96 \times 10^{-5} \\
{\left[\mathrm{Se}(\mathrm{IV}), \mathrm{ng} \mathrm{mL}^{-1}\right]} \\
\quad-1.19 \times 10^{-4}\end{array}$ & $\begin{array}{l}\Delta A_{3}=2.25 \times 10^{-4} \\
{\left[\mathrm{Se}(\mathrm{IV}), \mathrm{ng} \mathrm{mL}^{-1}\right]} \\
\quad-1.87 \times 10^{-4}\end{array}$ & $\begin{array}{l}\Delta A_{5}=3.46 \times 10^{-4} \\
{\left[\mathrm{Se}(\mathrm{IV}), \mathrm{ng} \mathrm{mL}^{-1}\right]} \\
\quad-8.86 \times 10^{-4}\end{array}$ & $\begin{array}{l}\Delta A_{7}=3.95 \times 10^{-4} \\
{\left[\mathrm{Se}(\mathrm{IV}), \mathrm{ng} \mathrm{mL}^{-1}\right]} \\
\quad-2.40 \times 10^{-3}\end{array}$ & $\begin{array}{l}\Delta A_{9}=4.64 \times 10^{-4} \\
{\left[\mathrm{Se}(\mathrm{IV}), \mathrm{ng} \mathrm{mL}^{-1}\right]} \\
\quad-2.55 \times 10^{-3}\end{array}$ & $\begin{array}{l}\Delta A_{12}=4.87 \times 10^{-4} \\
{\left[\mathrm{Se}(\mathrm{IV}), \mathrm{ng} \mathrm{mL}^{-1}\right]} \\
\quad-2.86 \times 10^{-3}\end{array}$ \\
\hline $\begin{array}{c}\text { Correlation } \\
\text { coefficient (r) }\end{array}$ & 0.9942 & 0.9955 & 0.9975 & 0.9985 & 0.9768 & 0.9634 \\
\hline $\begin{array}{c}{ }^{a} \text { Detection limit, } \\
\mathrm{ng} \mathrm{mL} \mathrm{mL}^{-1}\end{array}$ & 13.75 & 5.62 & 2.76 & 0.215 & 1.85 & 4.54 \\
\hline
\end{tabular}

${ }^{a}$ Based on statistical $3 \mathrm{~S}_{\text {blank }} / \mathrm{m}$-criterion for ten replicate blank absorbance change $\left(\Delta \mathrm{A}_{0}\right)$ measurements 


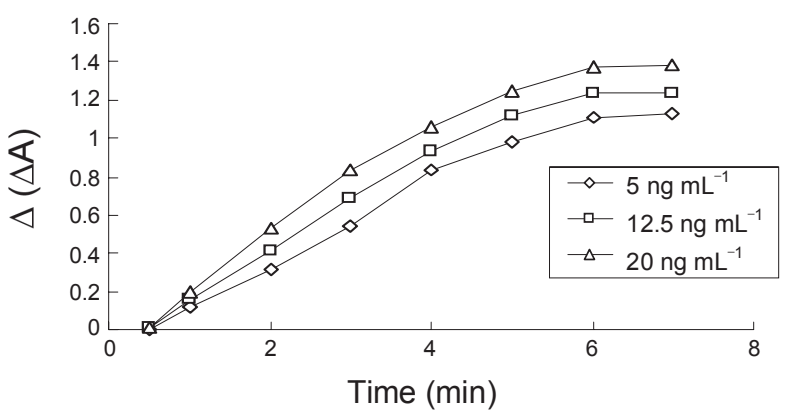

Figure 1. Effect of time on analytical sensitivity for the net reaction rates in the presence of $5,12.5$ and $20 \mu \mathrm{g} \mathrm{Se}(\mathrm{IV}) \mathrm{L}^{-1}$. Optimum conditions: $[$ Calmagite $]=12.5 \mathrm{mg} \mathrm{L}^{-1},\left[\mathrm{BrO}_{3}^{-}\right]=3.5 \times 10^{-3} \mathrm{M},[p$-nitrophenylhydrazine $]=2.5 \times 10^{-3} \mathrm{M}$, temperature $=25^{\circ} \mathrm{C}$, fixed-time, $7 \mathrm{~min}$ at $523 \mathrm{~nm}$.

of environment on analytical sensitivity, $\Delta(\Delta \mathrm{A})$ was investigated. It was found that the maximum change in absorbance as analytical signal $\left.\left(\Delta(\Delta \mathrm{A}): \Delta \mathrm{A}_{\mathrm{C}}-\Delta \mathrm{A}_{0}\right)\right)$ was occurred within the first 7 min passing after the initiation of the catalytic reaction. Under optimum conditions, it was found that there is a linear relationship with an increasing slope for the selenium concentrations of 5, 12.5 and $20 \mu \mathrm{g} \mathrm{L}^{-1}$ between analytical signal and reaction time for the first $7 \mathrm{~min}$. For this reason, the fixed-time measurement of 7-min was chosen as the most suitable reaction time for the determination of selenium in real samples (Figure 1).

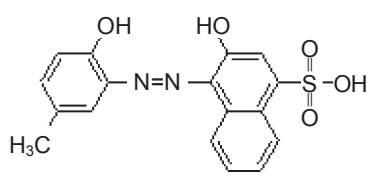

The catalytic reaction mechanism. Calmagite, with the chemical name of 2-hydroxy-1-(2-hydroxy-5-methylphenylazo)-4naphthalenesulfonic acid, is an azo dye, which is used as indicator for $\mathrm{Ca}^{2+}$ and $\mathrm{Mg}^{2+}$ ions in water hardness measurement and also used as a redox indicator. The decolorization of Calmagite in presence of bromate ion is quite slow in weak acidic media. However, Se(IV) catalytically accelerates this reaction in weak acidic media but the catalysis is too fast to be monitored spectrophotometrically. The addition of $p$-nitrophenylhydrazine in the reaction medium slows down the reaction rate. A reasonable catalytic route of $\mathrm{Se}$ is that the $p$-nitrophenylhydrazine reduce $\mathrm{Se}(\mathrm{IV})$ or $\mathrm{SeOBr}_{2}$ to elemental Se quantitatively in acidic medium as shown in Eq. (4). The elemental Se thus formed is oxidized back to $\mathrm{Se}$ (IV) by $\mathrm{BrO}_{3}{ }^{-}$, generating $\mathrm{Br}^{-}$\{Eq. (5) $\}$. The $\mathrm{Br}^{-}$in acidic medium is oxidized by $\mathrm{BrO}_{3}^{-}$to $\mathrm{Br}_{2}\{$ Eq. (6-7)\} which oxidizes i.e. decolorizes Calmagite as shown in Eq. (5) and similar observations have been obtained by other workers. Thus, the oxidation of Calmagite is significantly accelerated in presence of trace quantities of $\mathrm{Br}_{2}$ i.e. indirectly it is catalyzed in the presence of trace quantities of Se(IV) $\{\mathrm{Eq}$. (8)\}. An evident increase, which is observed in rate of Se(IV)-catalyzed reaction at $523 \mathrm{~nm}$ may be attributed to a formation of $\mathrm{SeOBr}_{2}$ as a reactive intermediate, formed in the activation step of indicator reaction with bromide as follows:

$$
\begin{aligned}
& \mathrm{H}_{2} \mathrm{SeO}_{3} \stackrel{\mathrm{p} K_{\mathrm{a}} 1: 2.64}{\longrightarrow} \mathrm{HSeO}_{3}^{-} \stackrel{\mathrm{pK}_{\mathrm{a}} 2: 8.36}{\longrightarrow} \mathrm{SeO}_{3}^{2-} \\
& \mathrm{H}_{2} \mathrm{SeO}_{3} \leftrightarrow \mathrm{H}_{2} \mathrm{O}+\mathrm{SeO}_{2} \\
& 2 \mathrm{Br}^{-}+\mathrm{O}=\mathrm{Se}=\mathrm{O}+2 \mathrm{H}^{+} \rightarrow \mathrm{O}=\mathrm{SeBr}_{2}+\mathrm{H}_{2} \mathrm{O}
\end{aligned}
$$

Again, dependence of catalyzed-reaction rate on acidity and activator concentration in determination of total selenium can be attributed to a nucleophilic attack of the bromide ion on protonated form of selenic acid in prereduction of $\mathrm{Se}(\mathrm{VI})$ to $\mathrm{Se}(\mathrm{IV})$ in acid medium in the temperature range of $20-35^{\circ} \mathrm{C}$.

$$
\begin{aligned}
& \mathrm{HSeO}_{4}^{-}+2 \mathrm{Br}^{-}+2 \mathrm{H}^{+} \leftrightarrow \mathrm{HSeO}_{3}^{-}+\mathrm{Br}_{2}+\mathrm{H}_{2} \mathrm{O} \\
& \mathrm{H}_{2} \mathrm{SeO}_{4}+\mathrm{H}^{+} \leftrightarrow \mathrm{H}_{3} \mathrm{SeO}_{4}^{+} \\
& \mathrm{H}_{3} \mathrm{SeO}_{4}^{+}+\mathrm{Br}^{-} \rightarrow \mathrm{HSeO}_{3} \mathrm{Br}+\mathrm{H}_{2} \mathrm{O}
\end{aligned}
$$

This intermediate product, $\mathrm{HSeO}_{3} \mathrm{Br}$ then undergoes further reactions, following the overall process:

$$
\mathrm{HSeO}_{3} \mathrm{Br}+\mathrm{H}_{2} \mathrm{O} \rightarrow \mathrm{H}_{2} \mathrm{SeO}_{3}+\mathrm{Br}^{+} \mathrm{OH}^{-}
$$

This interpretation based on consideration as a nucleophile rather than a reducing agent is also supported by the smaller reactivity of chloride ions as can be seen in Figure 8. As the formation of $\mathrm{Se}(\mathrm{IV})$ is controlled by reaction (2) as the rate determining step, rate of reactions summarized in Eq. (3) must be faster than the rate of the sequence (1) and (2). As reaction (3) is faster than reaction (2), no direct evidence is available about the sequence of steps in process (3). Nonlinear dependence of sensitivity as analytical signal on concentration of bromide ions may be due to participation of bromide ions in step (3). It could be concluded that the above observations and conclusions in this context will be useful in a development of a more reliable procedure for determination of $\mathrm{Se}(\mathrm{VI})$ in mixtures with $\mathrm{Se}(\mathrm{IV})$ in real samples.

$$
\begin{aligned}
& \mathrm{SeO}_{2}+\mathrm{H}^{+}+\mathrm{O}_{2} \mathrm{~N}-\mathrm{C}_{6} \mathrm{H}_{5}-\mathrm{NHNH}_{2} \\
& \stackrel{\text { Slow }}{\longrightarrow} \mathrm{Se}_{(k)}+\mathrm{N}_{2}+2 \mathrm{H}_{2} \mathrm{O}+\mathrm{O}_{2} \mathrm{~N}-\mathrm{C}_{6} \mathrm{H}_{5} \\
& 3 \mathrm{Se}+2 \mathrm{BrO}_{3}^{-}+3 \mathrm{H}_{2} \mathrm{O} \rightarrow 3 \mathrm{H}_{2} \mathrm{SeO}_{3}+2 \mathrm{Br}^{-} \\
& \mathrm{BrO}_{3}^{-}+5 \mathrm{Br}^{-}+6 \mathrm{H}^{+} \rightarrow 3 \mathrm{Br}_{2}+3 \mathrm{H}_{2} \mathrm{O}
\end{aligned}
$$

In the presence of $0.15 \mathrm{M} \mathrm{NaCl}$ or $\mathrm{NaCl}$ plus $\mathrm{NaBr}$,

$$
\begin{aligned}
& 10 \mathrm{Cl}^{-}+10 \mathrm{Br}^{-}+4 \mathrm{BrO}_{3}^{-}+24 \mathrm{H}^{+} \\
& \rightarrow 5 \mathrm{Cl}_{2}+7 \mathrm{Br}_{2}+12 \mathrm{H}_{2} \mathrm{O}
\end{aligned}
$$

$$
\begin{aligned}
& \mathrm{H}_{3} \mathrm{C}-(-\mathrm{OH})-\mathrm{C}_{6} \mathrm{H}_{4}-\mathrm{N}=\mathrm{N}-\mathrm{C}_{10} \mathrm{H}_{5}-(\mathrm{OH})-\mathrm{SO}_{3} \mathrm{H} \\
& +\mathrm{Br}_{2}+\mathrm{H}_{2} \mathrm{O} \rightarrow \mathrm{N}_{2}+\mathrm{Br}^{-} \\
& +\left[\mathrm{Br}-\mathrm{C}_{10} \mathrm{H}_{5}-(\mathrm{OH})-\mathrm{SO}_{3} \mathrm{H}+\mathrm{H}_{3} \mathrm{C}-(\mathrm{OH})-\mathrm{C}_{6} \mathrm{H}_{3}-\mathrm{OH}\right]
\end{aligned}
$$$$
\text { (degradation products) }
$$ 


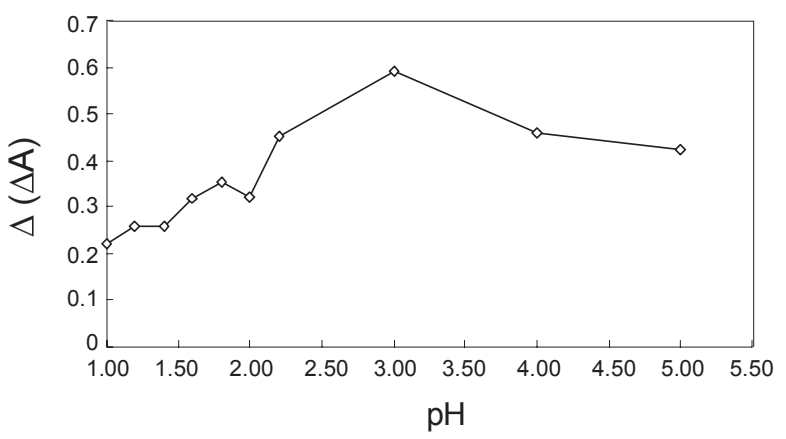

Figure 2. Effect of $\mathrm{pH}$ on analytical sensitivity for the net reaction rates. Optimum conditions: $[$ Calmagite $]=12.5 \mathrm{mgL}^{-1},\left[\mathrm{BrO}_{3}{ }^{-}\right]=3.5 \times$ $10^{-3} \mathrm{M},[p$-nitrophenylhydrazine $]=2.5 \times 10^{-3} \mathrm{M}$, temperature $=25^{\circ} \mathrm{C}$, fixed-time, $7 \mathrm{~min}$ at $523 \mathrm{~nm}$.

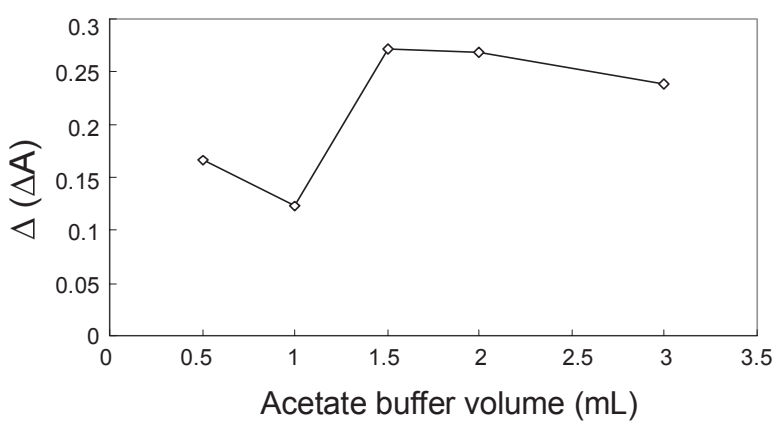

Figure 3. Effect of buffer volume on analytical sensitivity for the net reaction rates. Optimum conditions: $[$ Calmagite $]=12.5 \mathrm{mgL}^{-1},\left[\mathrm{BrO}_{3}^{-}\right]=$ $3.5 \times 10^{-3} \mathrm{M},[p$-nitrophenylhydrazine $]=2.5 \times 10^{-3} \mathrm{M}, \mathrm{pH} 3.0$ acetate buffer, temperature $=25^{\circ} \mathrm{C}$, fixed-time, $7 \mathrm{~min}$ at $523 \mathrm{~nm}$.

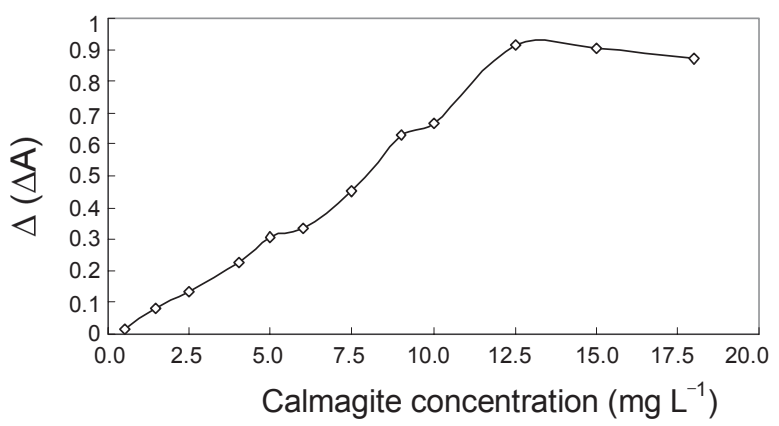

Figure 4. Effect of Calmagite concentration on analytical sensitivity for the net reaction rates. Optimum conditions: $\left[\mathrm{BrO}_{3}{ }^{-}\right]=3.5 \times 10^{-3} \mathrm{M}$, $[p$-nitrophenylhydrazine $]=2.5 \times 10^{-3} \mathrm{M}, 1.5 \mathrm{~mL} \mathrm{pH} 3.0$ acetate buffer, temperature $=25^{\circ} \mathrm{C}$, fixed-time, $7 \mathrm{~min}$ at $523 \mathrm{~nm}$.

It is well known ${ }^{38-42}$ that most indicator reactions used for kinetic-catalytic determination of selenium at trace amounts (where Methyl orange as chromogenic reagent is used) are based on oxidation-reduction reactions in which the catalyst that is usually a multi-charged ion such as $\mathrm{Se}(\mathrm{IV})$ and/or Se(VI) changes its oxidation state during the reaction especially in the presence of reducing agents such as hydrazine, hydroxyl amine and ascorbic acid. Therefore, the possible catalytic reaction mechanism for the indicator system in $\mathrm{pH} 3.0$ acetate buffer media may be suggested by a series of reactions as the above-

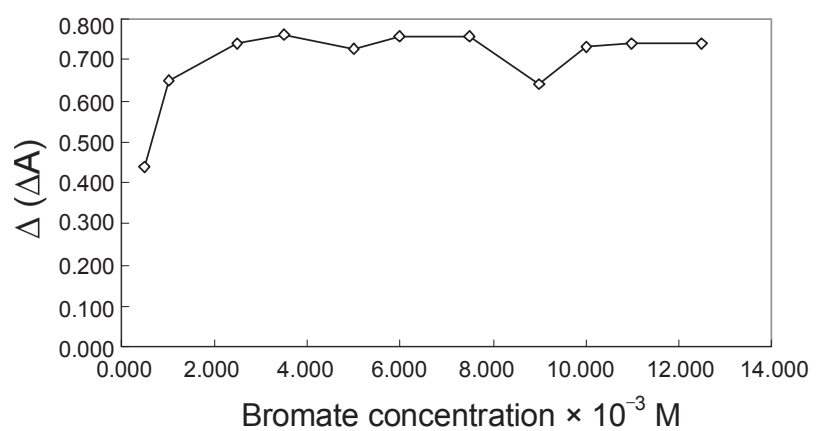

Figure 5. Effect of bromate concentration on analytical sensitivity for the net reaction rates. Optimum conditions: [Calmagite] $=12.5 \mathrm{mg} \mathrm{L}^{-1}$, $[p$-nitrophenylhydrazine $]=2.5 \times 10^{-3} \mathrm{M}, 1.5 \mathrm{~mL} \mathrm{pH} 3.0$ acetate buffer, temperature $=25^{\circ} \mathrm{C}$, fixed-time, $7 \mathrm{~min}$ at $523 \mathrm{~nm}$.

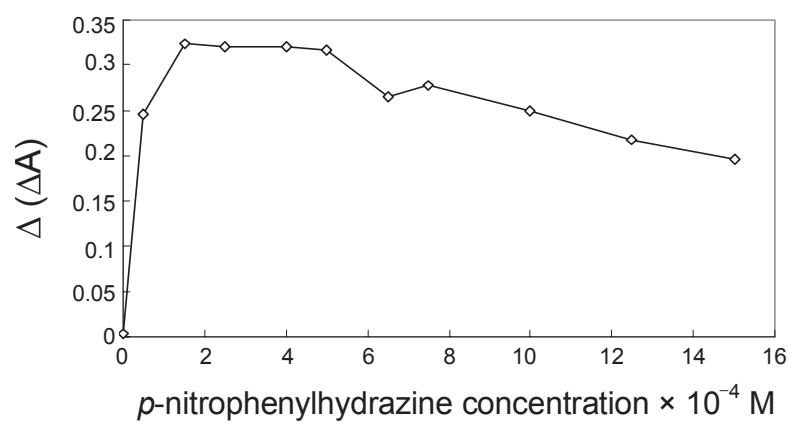

Figure 6. Effect of $p$-nitrophenylhydrazine concentration on analytical sensitivity for the net reaction rates. Optimum conditions: [Calmagite] = $12.5 \mathrm{mg} \mathrm{L}^{-1},\left[\mathrm{BrO}_{3}^{-}\right]=3.5 \times 10^{-3} \mathrm{M}, 1.5 \mathrm{~mL} \mathrm{pH} 3.0$ acetate buffer, temperature $=25^{\circ} \mathrm{C}$, fixed-time, $7 \mathrm{~min}$ at $523 \mathrm{~nm}$.

mentioned.

The optimization of analytical variables. The effect of $\mathrm{pH}$ on the rate of the net catalyzed reaction was studied in the $\mathrm{pH}$ range $1.0-5.0$ as shown in Figure 2. It can clearly be seen that the maximum sensitivity obtained near to 3.0 . Therefore, $\mathrm{pH} 3.0$ was chosen as optimum for further studies. In order to remain constant the $\mathrm{pH}$ of indicator system the effect of the buffer concentration was also examined. The results indicated that $1.5 \mathrm{~mL}$ was optimum amount of NaAc-HAc buffer (Figure 3).

The effect of calmagite concentration on reaction rates was studied for a concentration range of $0-20 \mathrm{mg} \mathrm{L}^{-1}$. The present study has shown that both the catalyzed and uncatalyzed reaction rates increase with increase in calmagite concentration up to $12.5 \mathrm{mg} \mathrm{L}^{-1}$ (Figure 4). For convenience and reliability, a calmagite concentration of $12.5 \mathrm{mg} \mathrm{L}^{-1}$ was chosen as optimum value for further studies.

The effect of the concentration of $\mathrm{BrO}_{3}{ }^{-}$on the net reaction rate was studied in its concentration range $5 \times 10^{-4}$ to $1.3 \times 10^{-2} \mathrm{M}$. Increasing concentration of $\mathrm{BrO}_{3}{ }^{-}$increases rates for both the uncatalyzed and catalyzed reactions in the range of $5 \times 10^{-4}$ to $7.5 \times 10^{-3} \mathrm{M}$. At the concentration range studied, the net reaction rate continued to increase with increasing concentration of $\mathrm{BrO}_{3}{ }^{-}$ (Figure 5). Hence, a concentration of $3.5 \times 10^{-3} \mathrm{M}$ was chosen for further studies.

The effect of the concentration of $p$-nitrophenylhydrazine was studied for the concentration range of $0-15 \times 10^{-4} \mathrm{M}$. The 


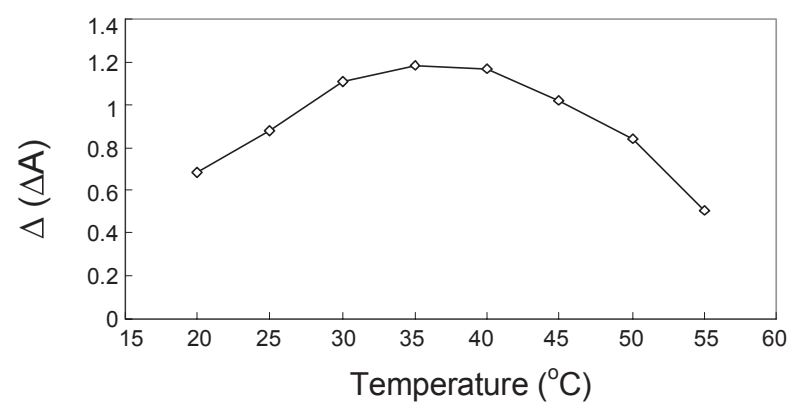

Figure 7. Effect of temperature on analytical sensitivity for the net reaction rates. Optimum conditions: [Calmagite $]=12.5 \mathrm{mg} \mathrm{L}^{-1},[p$-nitrophenylhydrazine $]=2.5 \times 10^{-3} \mathrm{M},\left[\mathrm{BrO}_{3}^{-}\right]=3.5 \times 10^{-3} \mathrm{M}, 1.5 \mathrm{~mL} \mathrm{pH} 3.0$ acetate buffer, fixed-time, $7 \mathrm{~min}$ at $523 \mathrm{~nm}$.

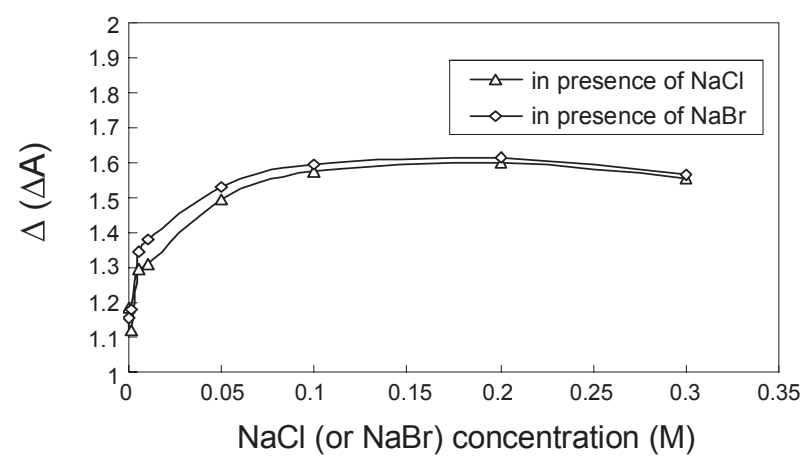

Figure 8. Effect of ionic strength on analytical sensitivity for the net reaction rates. Optimum conditions: [Calmagite] $=12.5 \mathrm{mg} \mathrm{L}^{-1},[p$ nitrophenylhydrazine $]=2.5 \times 10^{-3} \mathrm{M},\left[\mathrm{BrO}_{3}^{-}\right]=3.5 \times 10^{-3} \mathrm{M}, 1.5 \mathrm{~mL}$ $\mathrm{pH} 3.0$ acetate buffer, temperature $=25^{\circ} \mathrm{C}$, fixed-time, $7 \mathrm{~min}$ at $523 \mathrm{~nm}$.

plot of initial rate against the concentration of $p$-nitrophenylhydrazine is shown in Figure 6. It clearly indicates that the uncatalyzed and catalyzed reactions rates increase with increasing concentration of $p$-nitrophenylhydrazine until $2.5 \times 10^{-4} \mathrm{M}$, where the net reaction rate starts leveling off between the range of $(1.75-5.5) \times 10^{-4} \mathrm{M}$ (Figure 5). Therefore, $2.5 \times 10^{-4} \mathrm{M}$ was chosen as the optimum concentration of $p$-nitrophenylhydrazine.

Under the optimum conditions the effects of reaction temperature on the net reaction rate was investigated in the range of $20-55{ }^{\circ} \mathrm{C}$. It was observed that increasing temperature of the catalyzed and uncatalyzed reactions accompanied an increase in the rates of reaction. The temperature of $25{ }^{\circ} \mathrm{C}$ gives stable catalyzed reaction rates while the uncatalyzed reaction rate was relatively low and stable. Therefore, $25^{\circ} \mathrm{C}$ was the chosen temperature for all subsequent study and analyses (Figure 7).

The ionic strength dependence on the catalyzed and uncatalyzed reaction was studied in the range of $0-0.30 \mathrm{M}(\mathrm{NaCl}$ or $\mathrm{NaBr}$ ). A plot of ionic strength in terms of the concentration of $\mathrm{NaCl}$ or $\mathrm{NaBr}$ versus the net reaction rate showed that the catalytic reaction rates dramatically increased with increasing ionic strength up to $0.10 \mathrm{M}$ for both salt solutions. However, the analytical sensitivity in the presence of $\mathrm{NaBr}$ increased with a larger slope than those of $\mathrm{NaCl}$ in the range of $0-0.1 \mathrm{M}$. Therefore, a concentration of approximately $0.15 \mathrm{M}$ was considered as optimum value for further study (Figure 8).
Table 3. Effect of interfering ions on the determination of $12.5 \mu \mathrm{g} \mathrm{L}^{-1}$ $\mathrm{Se}(\mathrm{IV})$ under optimum conditions ([Calmagite] $=12.5 \mathrm{mg} \mathrm{L}^{-1},[p$ nitrophenylhydrazine $]=2.5 \times 10^{-3} \mathrm{M}, 1.5 \mathrm{~mL} \mathrm{pH} 3.0$ acetate buffer, temperature $=25^{\circ} \mathrm{C}$, fixed-time, $7 \mathrm{~min}$ at $523 \mathrm{~nm}$ ) and using the regression equation based on fixed time method given in Table 2

\begin{tabular}{cc}
\hline Interfering ion & $\begin{array}{r}\text { Tolerance limit, } \\
\mathrm{C}_{\text {interfering ion }} / \mathrm{C}_{\mathrm{Se}(\mathrm{IV})}\end{array}$ \\
\hline $\mathrm{K}^{+}, \mathrm{Na}^{+}, \mathrm{Li}^{+}, \mathrm{NH}_{4}{ }^{+}, \mathrm{Ca}^{2+}$ and $\mathrm{Mg}^{2+}$ & $5000^{a}$ \\
$\mathrm{Cl}, \mathrm{F}, \mathrm{CO}_{3}{ }^{2-}, \mathrm{HCO}_{3}, \mathrm{H}_{2} \mathrm{PO}_{4}^{-}, \mathrm{Mn}^{2+}, \mathrm{C}_{2} \mathrm{O}_{4}{ }^{2-}$, & 1000 \\
$\mathrm{CH}_{3} \mathrm{COO}^{-}$and $\mathrm{ClO}_{3}^{-}$ & 500 \\
$\mathrm{NO}_{3}{ }^{-}, \mathrm{Fe}^{2+}, \mathrm{Al}^{3+}, \mathrm{Cr}^{3+}, \mathrm{Zn}^{2+}$ and $\mathrm{Ni}^{2+}$ & 250 \\
$\mathrm{~V}^{4+}, \mathrm{Ce}^{3+}$ and $\mathrm{CrO}_{4}{ }^{2-}$ & 100 \\
$\mathrm{I}^{2}, \mathrm{C}_{2} \mathrm{O}_{4}{ }^{2-}, \mathrm{Sn}^{2+}$ and $\mathrm{SeO}_{4}{ }^{2-}$ & 75 \\
$\mathrm{~Pb}^{2+}, \mathrm{Co}^{2+}, \mathrm{MoO}_{4}{ }^{2-}, \mathrm{SO}_{3}{ }^{2-}, \mathrm{I}^{-}$ & 50 \\
$\mathrm{Cu}^{2+}, \mathrm{IO}_{3}^{-}, \mathrm{NO}_{2}^{-}, \mathrm{Br}^{-}, \mathrm{SCN}^{-}$ & 15 \\
$\mathrm{~V}^{5+}, \mathrm{Ce}^{4+}, \mathrm{As}^{3+}, \mathrm{Sb}^{3+}$ and Fe $^{3+}$ & 1 \\
$\mathrm{Hg}^{2+}$ & $750-1250^{b}$ \\
$\mathrm{Sn}^{2+}, \mathrm{Pb}^{2+}, \mathrm{Co}^{2+}, \mathrm{Cu}^{2+}, \mathrm{V}^{5+}, \mathrm{Ce}^{4+}, \mathrm{Fe}^{3+}, \mathrm{As}^{3+}$ and $\mathrm{Sb}^{3+}$ & \\
\hline
\end{tabular}

${ }^{a}$ Maximum tolerance limit tested. ${ }^{b}$ After using the cation-exchange resin.

Table 4. The accuracy and precision of the proposed kinetic method for the determination of $\mathrm{Se}(\mathrm{IV})$ and $\mathrm{Se}(\mathrm{VI})$ under the optimum conditions ([Calmagite $]=12.5 \mathrm{mg} \mathrm{L}^{-1},[p$-nitrophenylhydrazine $]=2.5 \times$ $10^{-3} \mathrm{M}, 1.5 \mathrm{~mL} \mathrm{pH} 3.0$ acetate buffer, temperature $=25^{\circ} \mathrm{C}$, fixedtime, $7 \mathrm{~min}$ at $523 \mathrm{~nm}$ )

\begin{tabular}{|c|c|c|c|c|}
\hline \multicolumn{2}{|c|}{ Added $\left(\mathrm{ng} \mathrm{mL} \mathrm{m}^{-1}\right)$} & \multirow{2}{*}{$\begin{array}{c}\text { Found } \\
\left(\mathrm{ng} \mathrm{mL}^{-1}\right)\end{array}$} & \multirow{2}{*}{$\begin{array}{l}\text { Precision } \\
\left(\mathrm{ng} \mathrm{mL} L^{-1}\right)^{a}\end{array}$} & \multirow{2}{*}{$\begin{array}{c}\text { Accuracy, } \\
\text { \%Relative } \\
\text { Error }^{b}\end{array}$} \\
\hline $\mathrm{Se}(\mathrm{IV})$ & $\mathrm{Se}(\mathrm{VI})$ & & & \\
\hline 2.0 & - & 2.10 & $\begin{array}{c}\mathrm{C}=2.10 \pm 0.05 \\
\mathrm{~S}_{\mathrm{C}}=0.10 \\
\mathrm{RSD}=4.76 \%\end{array}$ & 5 \\
\hline 10.0 & - & 9.92 & $\begin{array}{c}\mathrm{C}=9.92 \pm 0.07 \\
\mathrm{~S}_{\mathrm{C}}=0.14 \\
\mathrm{RSD}=1.41 \%\end{array}$ & -0.8 \\
\hline \multirow[t]{4}{*}{20.0} & - & 19.88 & $\begin{array}{c}\mathrm{C}=19.88 \pm 0.02 \\
\mathrm{~S}_{\mathrm{C}}=0.05 \\
\mathrm{RSD}=0.25 \%\end{array}$ & -0.6 \\
\hline & 3.0 & 3.05 & $\begin{array}{c}\mathrm{C}=3.05 \pm 0.02 \\
\mathrm{~S}_{\mathrm{C}}=0.04 \\
\mathrm{RSD}=1.31 \%\end{array}$ & 1.7 \\
\hline & 6.0 & 5.96 & $\begin{array}{c}\mathrm{C}=5.96 \pm 0.02 \\
\mathrm{~S}_{\mathrm{C}}=0.04 \\
\mathrm{RSD}=0.67 \%\end{array}$ & -0.7 \\
\hline & 12.0 & 12.12 & $\begin{array}{c}\mathrm{C}=12.12 \pm 0.03 \\
\mathrm{~S}_{\mathrm{C}}=0.07 \\
\mathrm{RSD}=0.58 \%\end{array}$ & 1.0 \\
\hline
\end{tabular}

${ }^{a}$ The mean plus its standard error $(\mathrm{C})$, standard deviation $\left(\mathrm{S}_{\mathrm{C}}\right)$ and relative standard deviation (RSD) for five replicate measurements. ${ }^{b}$ Accuracy $=[$ (Found-Added $) /$ Added $] \times 100$.

\section{Analytical data.}

Analysis by the fixed-time method: Calibration graph of change in absorbance at a fixed time $\left(\Delta(\Delta \mathrm{A})_{t}\right)$ versus concentration of $\mathrm{Se}(\mathrm{IV})$ at eight different concentrations were plotted at a fixed time $(t=1,3,5,7,9$ and $12 \mathrm{~min})$ in the range $1-35 \mu \mathrm{g} \mathrm{L}^{-1}$. 
Table 5. Determination of $\mathrm{Se}(\mathrm{IV})$ and $\mathrm{Se}(\mathrm{VI})$ in natural river water ${ }^{a}$ and lake water ${ }^{b}$ samples

\begin{tabular}{ccccc}
\hline \multirow{2}{*}{ Sample } & \multicolumn{2}{c}{$\mathrm{Se}(\mathrm{IV}), \mathrm{ng} \mathrm{mL}^{-1}$} & \multicolumn{2}{c}{$\mathrm{Se}(\mathrm{VI}), \mathrm{ng} \mathrm{mL}^{-1}$} \\
\cline { 2 - 5 } & Added & Found $^{c}$ & Added & Found $^{c}$ \\
\hline & - & $1.39 \pm 0.03$ & - & $2.68 \pm 0.03$ \\
River water & 10.0 & $6.43 \pm 0.03$ & - & - \\
(Kizilırmak, & 20.0 & $21.36 \pm 0.02$ & - & - \\
Sivas) & - & - & 5.0 & - \\
& - & - & 10.0 & $9.92 \pm 0.03 \pm 0.02$ \\
& - & - & 20.0 & $19.94 \pm 0.02$ \\
Lake water & 10.0 & $9.97 \pm 0.03$ & - & $<0.2$ \\
(Hafik, & 20.0 & $19.95 \pm 0.03$ & - & - \\
Sivas) & - & - & 5.0 & $4.98 \pm 0.04$ \\
& - & - & 10.0 & $10.3 \pm 0.03$ \\
& - & - & 20.0 & $20.05 \pm 0.02$ \\
\hline
\end{tabular}

${ }^{a}$ The river water samples were collected from Kizılirmak River, Sivas in Turkey on June 2009. ${ }^{b}$ The lake water samples were collected from Hafik Lake, Sivas in Turkey on June 2009. ${ }^{c}$ Average of six replicate determinations \pm S.D.

It is apparent from Table 2 that the values of error, RSDs and detection limits were found to be lowest for fixed time of $7 \mathrm{~min}$ for 1 - $35 \mu \mathrm{g} \mathrm{L}{ }^{-1} \mathrm{Se}(\mathrm{IV})$, respectively. Therefore, the fixed time of 7 min was adopted with the highest sensitivity and correlation coefficient for the analysis of inorganic Se in water samples.

Selectivity of indicator reaction: In order to establish the application of the proposed method to environmental samples, the selectivity of the proposed method was evaluated by determining $15 \mu \mathrm{g} \mathrm{L}^{-1}$ of Se(IV) in the presence of varying amounts of cations and anions which are commonly present in environmental waters. The tolerance limit was defined as the concentration of an added ion causing not more than $\pm 3 \%$ relative error $^{43}$ and the results are summarized inTable 3 . The interference effect of cations could be removed by passing the solution through a column containing a strongly cation-exchange resin. The tolerance limit was increased up to a value changing the range of 750 - 1250 for each interfering species with Amberlite IR120 plus as a cation-exchange resin. It was found that many of these ions did not interfere, even when present in excess of 5000 to 50 fold. Those ions which interfere, if present greater than 10 fold excess, are seldom present at the concentrations levels tested in natural waters. ${ }^{44}$ Thus the proposed method is suitable for the determination of inorganic Se in environmental waters in presence of its natural constituents.

The accuracy and precision of the proposed kinetic method: The accuracy and precision of the proposed kinetic method was established by determining the content of Se at different concentration levels in spiked water (in the range of $2-20 \mu \mathrm{g} \mathrm{L}^{-1}$ ) for the determination and speciation of Se. The results of the recoveries by using fixed time method along with standard error (SE) and standard deviation (SD) are presented in Table 4. The recoveries data presented are quite satisfactory. Thus, it can be expressed that the proposed kinetic method may be very effective in the analysis of inorganic Se in water samples.

The analytical applications of the proposed kinetic method: In order to evaluate the analytical applicability of the proposed method it was applied to the determination of selenium in natural water samples. The water samples were collected and filtered and their selenium contents were measured by the proposed method after removing the cationic interference species with Amberlite IR120 plus (Table 5). As this table shows, the results of the recovery of added $\mathrm{Se}(\mathrm{IV})$ and $\mathrm{Se}(\mathrm{VI})$ were satisfactory. Additionally, the proposed method was applied to a standard reference material, NIST SRM 1643e "Trace Elements in Water", with a selenium content of $11.97 \pm 0.14 \mu \mathrm{g} \mathrm{L}^{-1}$. Mass concentrations of SRM 1643e were calculated using the measured density of $1.025 \mathrm{~g} \mathrm{~mL}^{-1}$. Using the proposed method, the content of Se in this SRM was $11.92 \pm 0.03 \mu \mathrm{g} \mathrm{L}^{-1}$. A comparison using $t$-test, demonstrate that there is not significant difference among the achieved results using the proposed method and the certified values. By the other way, Certified Reference Material of River Water or Natural Water with certified values for Se(IV) and $\mathrm{Se}(\mathrm{VI})$ do not exist however, the method of standard addition is considered as a validation method, ${ }^{45}$ therefore, increasing quantities of $\mathrm{Se}(\mathrm{IV})$ and $\mathrm{Se}(\mathrm{VI})$ were added to the river samples and $\mathrm{Se}(\mathrm{IV})$ and $\mathrm{Se}(\mathrm{VI})$ were determined by the proposed method (Table 5).

\section{Conclusions}

The developed kinetic method can be used to determine selenium at levels as low as $0.215 \mu \mathrm{g} \mathrm{L}^{-1}$ without the need for any preconcentration step. This novel kinetic technique is suitable for the determination of the speciation of $\mathrm{Se}(\mathrm{IV})$ and $\mathrm{Se}(\mathrm{VI})$ in environmental samples either directly analyzing them or after removal of potential interfering cationic species using a strongly cation-exchange resin such as Amberlite IR120 plus when being necessary. The proposed method has the advantages of low cost, simple operation, a linear range of 35 fold, reproducibility, accuracy and, most importantly, low DLs, comparable with the DLs obtained by the existing catalytic kinetic techniques. ${ }^{23-36}$ As a result, the proposed kinetic method can be simply replaced by the use of common chromatographic and atomics spectroscopic method with speedy analysis in order to determine and speciate inorganic Se and Se species in a simple matrix such as environmental surface waters. In addition, kinetic methods available, especially for use in underdeveloped and developing countries in order to detect the selenium present in real life samples can routinely be utilized for a local laboratory.

Acknowledgments. Authors wish to express their graduate to Professor Mehmet AKÇAY for all expertly discussions with him during his stay at University and were exchanged in a number of e-mails even after his departure, as all of his suggestions contributed enormously in the preparation of this manuscript.

\section{References}

1. NeÁve, J.; Henry, M.; Peretz, A.; Mareschi, J. P. Cah. Nutr. DieÂt. 1987, 22, 145.

2. Frost, D. V. Crit. Rev. Toxicol. 1972, 467. 
3. El-Shahawi, M. S.; Othman, A. M.; Othman A. S.; El-Sonbati, M. A. Int. J. Environ. Anal. Chem. 2006, 86, 941-954.

4. D'Ulivo, A. Analyst 1997, 122, 117R-144R.

5. Capelo, J. L.; Fernandez, C.; Pedras, B.; Santos, P.; Gonzalez, P.; Vaz, C. Talanta 2005, 68, 1442-1447.

6. Saygi, K. O.; Melek, E.; Tuzen, M.; Soylak, M. Talanta 2007, 71, $1375-1381$

7. Oram, L. L.; Strawn, D. G.; Marcus, M. A.; Fakra, S. C.; Moller, G. Environ. Sci. Technol. 2008, 42, 6830-6836

8. Tuzen, M.; Saygi, K. O.; Soylak, M. Talanta 2007, 71, 424-429.

9. Campanella, L.; Ferri, T.; Morabito, R. A. Analysis 1989, 17, 507.

10. Kumar, A. R.; Riyazuddin, P. Int. J. Environ. Anal. Chem. 2007, 87, 469-500.

11. de Souza, S. S.; Santos, D., Jr.; Krug, F. J.; Barbosa, F., Jr. Talanta 2007, 73, 451-457.

12. Zhang, L.; Morita, Y.; Sakuragawa, A.; Isozaki, A. Talanta 2007, $72,723-729$.

13. Rurikova, D.; Tothova, E. Chem. Papers 1999, 53, $26-33$.

14. Sucharova, J.; Suchara, I. Anal. Chim. Acta 2006, 576, 163-176.

15. Wallschlager, D.; Roehl, R. J. Anal. Atom. Spectr. 2001, 16, $922-$ 925.

16. El-Shahawi, M. S.; El-Sonbati, M. A. Talanta 2005, 67, 806-815.

17. Stripeikis, J.; Costa, P.; Tudino, M.; Troccoli, O. Anal. Chim. Acta 2000, 408, 191.

18. Naik, R. M.; Srivastava, A.; Prasad, S. Spectrochim. Acta Pt. A: Mol. Biomol. Spectrosc. 2008, 69, 193-197.

19. Naik, R. M.; Sarkar, J.; Prasad, S. Microchem. J. 2008, 88, 45-51.

20. Prasad, S. Anal. Lett. 2004, 37, 2851-2867.

21. Prasad, S. J. Anal. Chem. 2005, 60, 581-588.

22. Prasad, S. Microchem. J. 2007, 85, 214-221.

23. Martinez Lozano, C.; Perez Ruiz, T.; Tomas, V.; Abellan, C. Analyst 1989, 114, 715.

24. Gökmen, I. G.; Abdelkader, E. Analyst 1994, 119, 703.

25. Ensafi, A. A.; Bagherian Dehaghi, G. Anal. Lett. 1995, 28(2), 335-
347.

26. Safavi, A.; Afkhami, A. Anal. Lett. 1995, 28, 1095.

27. Safavi, A.; Sedghi, H. R.; Shams, E. Fresenius J. Anal. Chem. 1999, 365, 504.

28. Afkhami, A.; Madrakian, T. Talanta 2002, 58, 311-317.

29. Songsasen, A.; Aukkarayunyong, P.; Bangkedphol, S.; Sasomsap, W. Kasetsart J. Nat. Sci. 2002, 36, 103-109.

30. Gurkan, R.; Akcay, M. Microchem. J. 2003, 75, 39-49.

31. Ensafi, A. A.; Lemraski, M. S. Anal. Lett. 2004, 37, 2469-2483.

32. Nakano, S.; Yoshii, M.; Kawashima, T. Talanta 2004, 64, 12661272.

33. Gudzenko, L. V.; Pantaler, R. P.; Blank, A. B. J. Anal. Chem. 2004, 59, 935-938.

34. Zhengjun, G.; Xinshen, Z.; Guohe, C.; Xinfeng, X. Talanta 2005, $66,1012-1017$

35. Keyvanfard, M.; Sharifian, A. J. Anal. Chem. 2006, 61, 596-600.

36. Chand, V.; Prasad, S. J. Hazardous Mater. 2009, 165(1-3), 780788.

37. Brimmer, P.; Fawcett, W.; Kulhavy, A. Anal. Chem. 1987, 59, 14701471.

38. Afkhami, A.; Madrakian, T. Talanta 2002, 58, 311-317.

39. Safavi, A.; Absalan, G.; Maesum, S. Anal. Chim. Acta 2001, 432, 229-233.

40. Linares, P.; Castro, L. D.; Valcarcel, M. Analyst 1986, 111, $1405-$ 1407.

41. Afkami, A.; Afshar-E-Asl, A. Anal. Chim. Acta 2000, 419, 101106.

42. Afkhami, A.; Mosaed, F. Anal. Sci. 2002, 18, 667-670.

43. Prasad, S. Anal. Chim. Acta 2005, 540, 173-180.

44. Pais, I.; Jones, B. J., Jr. The Handbook of Trace Elements; St. Louis Press: 1997; Florida.

45. Pichard, E.; MacKay, G. M.; Pionts, J. Trace Analysis: A Structured Approach to Obtaining Reliable Results; the Royal Society of Chemistry: 1996; UK, p 38. 